\title{
Characterization of Atomic and Physical Properties of Biofield Energy Treated Manganese Sulfide Powder
}

\author{
Mahendra Kumar Trivedi ${ }^{1}$, Rama Mohan Tallapragada ${ }^{1}$, Alice Branton ${ }^{1}$, Dahryn Trivedi ${ }^{1}$, \\ Gopal Nayak ${ }^{1}$, Omprakash Latiyal ${ }^{2}$, Snehasis Jana ${ }^{2, *}$ \\ ${ }^{1}$ Trivedi Global Inc., Henderson, USA \\ ${ }^{2}$ Trivedi Science Research Laboratory Pvt. Ltd., Bhopal, Madhya Pradesh, India
}

Email address:

publication@trivedisrl.com (S. Jana)

\section{To cite this article:}

Mahendra Kumar Trivedi, Rama Mohan Tallapragada, Alice Branton, Dahryn Trivedi, Gopal Nayak, Omprakash Latiyal, Snehasis Jana. Characterization of Atomic and Physical Properties of Biofield Energy Treated Manganese Sulfide Powder. American Journal of Physics and Applications. Vol. 3, No. 6, 2015, pp. 215-220. doi: 10.11648/j.ajpa.20150306.15

\begin{abstract}
Manganese sulfide (MnS) is known for its wide applications in solar cell, opto-electronic devices, and photochemical industries. The present study was designed to evaluate the effect of biofield energy treatment on the atomic and physical properties of $\mathrm{MnS}$. The $\mathrm{MnS}$ powder sample was equally divided into two parts, referred as to be control and to be treated. The treated part was subjected to Mr. Trivedi's biofield energy treatment. After that, both control and treated samples were investigated using X-ray diffraction (XRD), Fourier transform infrared (FT-IR) spectroscopy, and electron spin resonance (ESR) spectroscopy. The XRD data revealed that the biofield energy treatment has altered the lattice parameter, unit cell volume, density, and molecular weight of the treated $\mathrm{MnS}$ sample as compared to the control. The crystallite size on various planes was significantly changed from $-50.0 \%$ to $33.3 \%$ in treated sample as compared to the control. The FT-IR analysis exhibited that the absorption band attributed to Mn-S stretching vibration was reduced from $\left(634 \mathrm{~cm}^{-1}\right)$ to $613 \mathrm{~cm}^{-1}$ in treated $\mathrm{MnS}$ as compared to the control. Besides, the ESR study revealed that g-factor was reduced by $3.3 \%$ in the treated sample as compared to the control. Therefore, the biofield energy treated MnS could be applied for the use in solar cell and semiconductor applications.
\end{abstract}

Keywords: Manganese Sulfide, Biofield Energy Treatment, X-Ray Diffraction, Fourier transform Infrared, Electron Spin Resonance

\section{Introduction}

Manganese chalcogenides $\mathrm{MnX}(\mathrm{X}=\mathrm{O}, \mathrm{S}, \mathrm{Se}, \mathrm{Te})$ are known for their interesting electronic structure and magnetooptical properties. The variable oxidation states and less toxicity of these compounds make them promising materials in wide range of application [1]. The Manganese sulfide $(\mathrm{MnS})$, a part of manganese chalcogenides family, is a wide band semiconductor with an energy band gap of $3.1 \mathrm{eV}$. It usually exist in three forms as $\alpha-\mathrm{MnS}, \beta-\mathrm{MnS}$, and $\gamma-\mathrm{MnS}$ [2-4]. The $\mathrm{MnS}$ is used in various application such as solar cell, opto-electronic devices, and photochemical materials [5, 6]. Currently, it is synthesized using various methods including hydrothermal method [7, 8], chemical bath deposition [9], solvothermal synthesis [10], etc. For industrial applications, the crystal structure, physical and atomic properties of $\mathrm{MnS}$ play an important role. Further, a considerable effort has been made by researchers to modify the crystalline phases and surface morphologies of MnS [11, 12]. Veeramanikandasamy et al. had modified the microstructure and optical properties of $\mathrm{MnS}$ using different $\mathrm{Mn} / \mathrm{S}$ ratio [13]. Further, Shi et al. had studied the effect of hydrothermal annealing on the structure, morphology and optical properties of $\mathrm{MnS}$ films [14]. However, all these process are very complex and costly, thus an economically viable approach is needed to modify the $\mathrm{MnS}$ with respect to physical and atomic properties. Recently, the biofield energy treatment have gained significant attention due to its potential effect on various living and non-living things $[15,16]$.

It is well established that the energy can be transferred from one place to another place using several scientific techniques. Further, it exists in various forms such as thermal, electric, kinetic, nuclear, etc. The living organisms are exchanging their energy with the environment for their 
health maintenance [17]. Moreover, a human has the capability to harness the energy from the environment/Universe and transmit it to any object around the Globe. The object(s) receive the energy and respond in a useful way that is called biofield energy, and this process is known as biofield energy treatment. The National Center for Complementary and Alternative Medicine (NCCAM) has recommended the use of alternative CAM therapies (e.g. healing therapy) in the healthcare sector [18]. Moreover, Mr. Trivedi's unique biofield energy treatment (The Trivedi Effect $^{\circledR}$ ) had been extensively studied in materials science [19]. It has substantially altered the atomic, physical and thermal properties in metals [20, 21] and ceramics [22]. Thus, after considering the effect of biofield energy treatment on metals and ceramics, this study was designed to evaluate the effect of this treatment on the atomic and physical properties of the MnS using X-ray diffraction (XRD), Fourier transform infrared (FT-IR) spectroscopy, and electron spin resonance spectroscopy (ESR).

\section{Materials and Methods}

The MnS powder was purchased from Sigma Aldrich, USA. The MnS powder sample was divided in two groups: to be control and to be treated. The control sample was remained as untreated, while the treated sample was in sealed pack, handed over to Mr. Trivedi for biofield energy treatment under standard laboratory condition. Mr. Trivedi provided the treatment through his energy transmission process to the treated sample without touching the sample. The control and treated MnS samples were analyzed using XRD, FT-IR, and ESR techniques.

\subsection{XRD Study}

The Phillips, Holland PW 1710 X-ray diffractometer system was used to perform the XRD analysis of control and treated MnS samples. From the XRD system, the data was obtained in the form of a table containing Bragg angles, the peak intensity counts, relative intensity $(\%)$, d-spacing value $(\AA)$, and full width half maximum (FWHM) $\left(\theta^{\circ}\right)$ for each peak. After that, the PowderX software was used to calculate the crystal structure parameters such as lattice parameter, and unit cell volume of the control and treated samples. Also, the Scherrer equation was used to compute the crystallite size on various planes as below equation 1 :

$$
\text { Crystallite size }(G)=\frac{k \lambda}{b \cos \theta}
$$

Here, $\mathrm{k}$ is equipment constant $(=0.94), \lambda=1.54056 \AA$, and $\mathrm{b}$ is full width half maximum (FWHM). After that, the percentage change in $G$ was calculated using following formula equation 2 :

$$
\text { Percent change in crystallite size }(G)=\frac{G_{t}-G_{c}}{G_{c}} \times 100
$$

Where, $G_{c}$ and $G_{t}$ are the crystallite size of control and treated $\mathrm{MnS}$ samples respectively.

\subsection{FT-IR Spectroscopy}

The FT-IR analysis of control and treated $\mathrm{MnS}$ was accomplished on Shimadzu's Fourier transform infrared spectrometer (Japan). The spectra was obtained with frequency range of $4000-500 \mathrm{~cm}^{-1}$. The purpose of the FT-IR analysis was to study the impact of biofield energy treatment on dipole moment, force constant and bond strength in the MnS.

\subsection{ESR Spectroscopy}

The ESR analysis of control and treated MNS samples was carried out using Electron Spin Resonance (ESR), E-112 ESR Spectrometer, Varian, USA. The X-band microwave frequency $(9.5 \mathrm{GHz})$, with sensitivity of $5 \times 10^{10}, \Delta \mathrm{H}$ spins was used for the ESR study.

\section{Results and Discussion}

\subsection{XRD Study}

The XRD technique is a quantitative and non-destructive technique, which is commonly used to study the crystal structure and its parameters of a compound. Fig. 1 shows the XRD diffractograms of control and treated MnS samples. The control MnS sample showed the intensive XRD peaks at

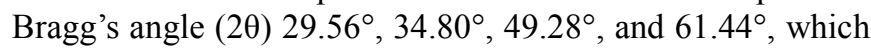
were corresponded to the crystalline plane (111), (200), (220), and (222) of cubic crystal structure according to joint committee on powder diffraction standards (JCPDS) card no. 06-0518.[23]. Further, the treated MnS sample exhibited the crystalline peaks at lower Bragg's angle $29.53^{\circ}, 34.25^{\circ}$, $49.26^{\circ}$, and $61.40^{\circ}$ corresponding to planes (111), (200), (220), and (222) respectively, as compared to the control. It was reported that the internal strain leads to shift the XRD pattern toward lower Bragg's angles. Thus, it is possible that the energy transferred through biofield treatment may provide the stress in the $\mathrm{MnS}$ sample and that might be responsible for the internal strain in treated $\mathrm{MnS}$ sample. Moreover, the crystallite sizes $(\mathrm{G})$ computed using Scherrer equation $(\mathrm{G}=\mathrm{k} \lambda / \mathrm{b} \cos \theta)$ is presented in Table 1 . The data showed that the crystallite size on crystalline peak (111) was increased from $107 \mathrm{~nm}$ (control) to $142.6 \mathrm{~nm}$ in the treated $\mathrm{MnS}$ sample. However, the crystallite sizes on most intense planes (200) and (220) were reduced from $144.6 \mathrm{~nm}$ and $227.7 \mathrm{~nm}$ (control) to 86.6 and $113.8 \mathrm{~nm}$, respectively, in treated $\mathrm{MnS}$ sample. It indicates that the crystallite size was significantly reduced by 40.1 and $50.0 \%$ on planes (200) and (220), respectively as compared to the control (Fig 2). Nevertheless, the crystallite size was remained same in control and treated MnS sample on crystalline plane (222). It was reported that presence of internal strain leads to fracture the crystallite into sub-crystallites [24]. Due to this, the crystallite size of treated $\mathrm{MnS}$ might reduce along some crystalline planes. Besides, the crystal structure parameters of $\mathrm{MnS}$ sample were computed using PowderX software and presented in Table 2. The data exhibited that the lattice 
parameter of unit cell was increased from $5.225 \AA$ (control) to $5.228 \AA$ in treated $\mathrm{MnS}$ sample. The increase in lattice parameter of unit cell was supported by the shifting of the XRD peaks toward lower Bragg angle [25]. In addition, the increase in lattice parameter in treated $\mathrm{MnS}$ samples led to increase the unit cell volume from $14.27 \times 10^{-23} \mathrm{~cm}^{3}$ (control) to $14.29 \times 10^{-23} \mathrm{~cm}^{3}$. It is well known that the unit cell volume and its density are inversely related. Thus, the increase in unit cell volume led to reduce the density from $4.084 \mathrm{~g} / \mathrm{cc}$ (control) to $4.078 \mathrm{~g} / \mathrm{cc}$. However, the molecular weight was increased from $87.66 \mathrm{~g} / \mathrm{mol}$ (control) to $87.79 \mathrm{~g} / \mathrm{mol}$ in treated MnS. Thus, the above results suggested that the biofield energy treatment probably acted at atomic level to cause these modifications. It is supposed that the energy transferred through biofield treatment could be in the form of the neutrinos, which probably acted at nuclear level to cause these alterations. Besides, Girish et al. reported that the energy band gap of $\mathrm{MnS}$ is directly related with its crystallite size and lattice strain [26]. Thus, the change in crystallite size and lattice strain in treated $\mathrm{MnS}$ may lead to alter its energy band gap. It is assumed that the biofield energy treatment could be used to modify the optical properties of MnS for solar cell and semiconductor applications. However, further study is required to confirm the actual change in optical properties of MnS after biofield energy treatment.
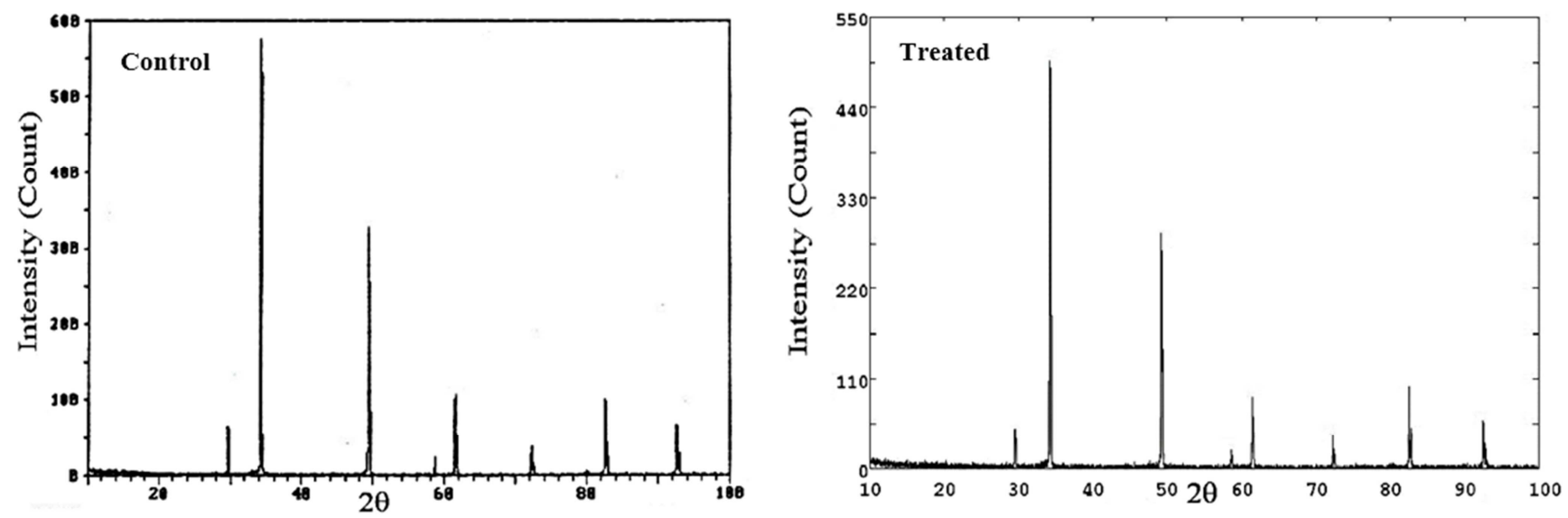

Fig. 1. X-ray diffractogram of manganese sulfide nanopowder.

Table 1. Effect of biofield energy treatment on crystallite size of manganese sulfide nanopowder.

\begin{tabular}{|c|c|c|c|c|c|c|}
\hline \multirow{2}{*}{$\begin{array}{l}\text { Plane } \\
\text { (hkl) }\end{array}$} & \multicolumn{3}{|c|}{ Control } & \multicolumn{3}{|c|}{ Treated } \\
\hline & $\begin{array}{l}20 \\
\left({ }^{\circ}\right) \\
\end{array}$ & $\begin{array}{l}\text { FWHM } \\
\left({ }^{\circ}\right)\end{array}$ & $\begin{array}{l}\text { G } \\
(\mathrm{nm})\end{array}$ & $2 \theta\left({ }^{\circ}\right)$ & $\begin{array}{l}\text { FWHM } \\
\left({ }^{\circ}\right)\end{array}$ & G (nm) \\
\hline 111 & 29.56 & 0.08 & 107.0 & 29.53 & 0.06 & 142.6 \\
\hline 200 & 34.80 & 0.06 & 144.6 & 34.25 & 0.10 & 86.6 \\
\hline 220 & 49.28 & 0.04 & 227.7 & 49.26 & 0.08 & 113.8 \\
\hline 222 & 61.44 & 0.08 & 120.4 & 61.40 & 0.08 & 120.4 \\
\hline
\end{tabular}

$2 \theta$ is Bragg angle, FWHM is full width half maximum of peaks, and G is crystallite size

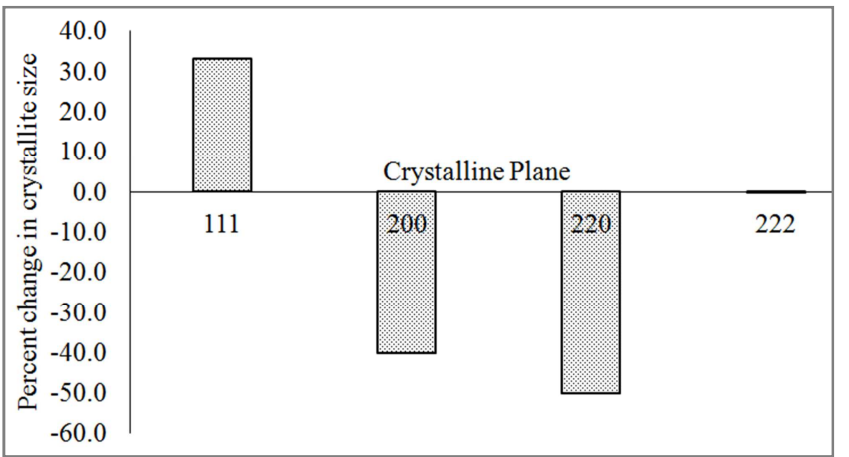

Fig. 2. The percent change in crystallite size of manganese sulfide powder after biofield energy treatment.
Table 2. Effect of biofield energy treatment on lattice parameter, unit cell volume density atomic weight, nuclear charge per unit volume of manganese sulfide nanopowder.

\begin{tabular}{lllll}
\hline Group & $\begin{array}{l}\text { Lattice } \\
\text { parameter } \\
(\mathbf{\AA})\end{array}$ & $\begin{array}{l}\text { Unit cell } \\
\text { volume }\left(\times \mathbf{1 0}^{-\mathbf{2 3}}\right. \\
\left.\mathbf{c m}^{\mathbf{3}}\right)\end{array}$ & $\begin{array}{l}\text { Density } \\
(\mathbf{g} / \mathbf{c c})\end{array}$ & $\begin{array}{l}\text { Molecular } \\
\text { weight } \\
(\mathbf{g} / \mathbf{m o l})\end{array}$ \\
\hline Control & 5.2257 & 14.270 & 4.084 & 87.660 \\
Treated & 5.2283 & 14.292 & 4.078 & 87.792 \\
\hline
\end{tabular}

\subsection{FT-IR Spectroscopy}

The FT-IR spectra of control and treated MnS samples are presented in Fig. 3. The spectra showed the absorption bands at $3439 \mathrm{~cm}^{-1}$ and $3450 \mathrm{~cm}^{-1}$ in control and treated sample, respectively, attributing to $-\mathrm{OH}$ stretching vibration. The bending vibrations of $\mathrm{O}-\mathrm{H}$ were found at $1642 \mathrm{~cm}^{-1}$ and 1648 $\mathrm{cm}^{-1}$ in control and treated samples respectively. It could be due to moisture absorption by the sample [27]. Furthermore, the control sample showed the absorption band at $634 \mathrm{~cm}^{-1}$ which was corresponded to Mn-S stretching vibrations.

However, in treated $\mathrm{MnS}$ sample, the absorption band attributing to $\mathrm{Mn}-\mathrm{S}$ stretching vibrations was shifted to lower wavenumber i.e. $613 \mathrm{~cm}^{-1}$ [28]. It was reported that the wavenumber $(\bar{v})$ is directly related to the bond force constant (k) as following equation 3 below [29]:

$$
\bar{v}=\frac{1}{2 \pi c} \sqrt{\frac{k}{\mu}}
$$



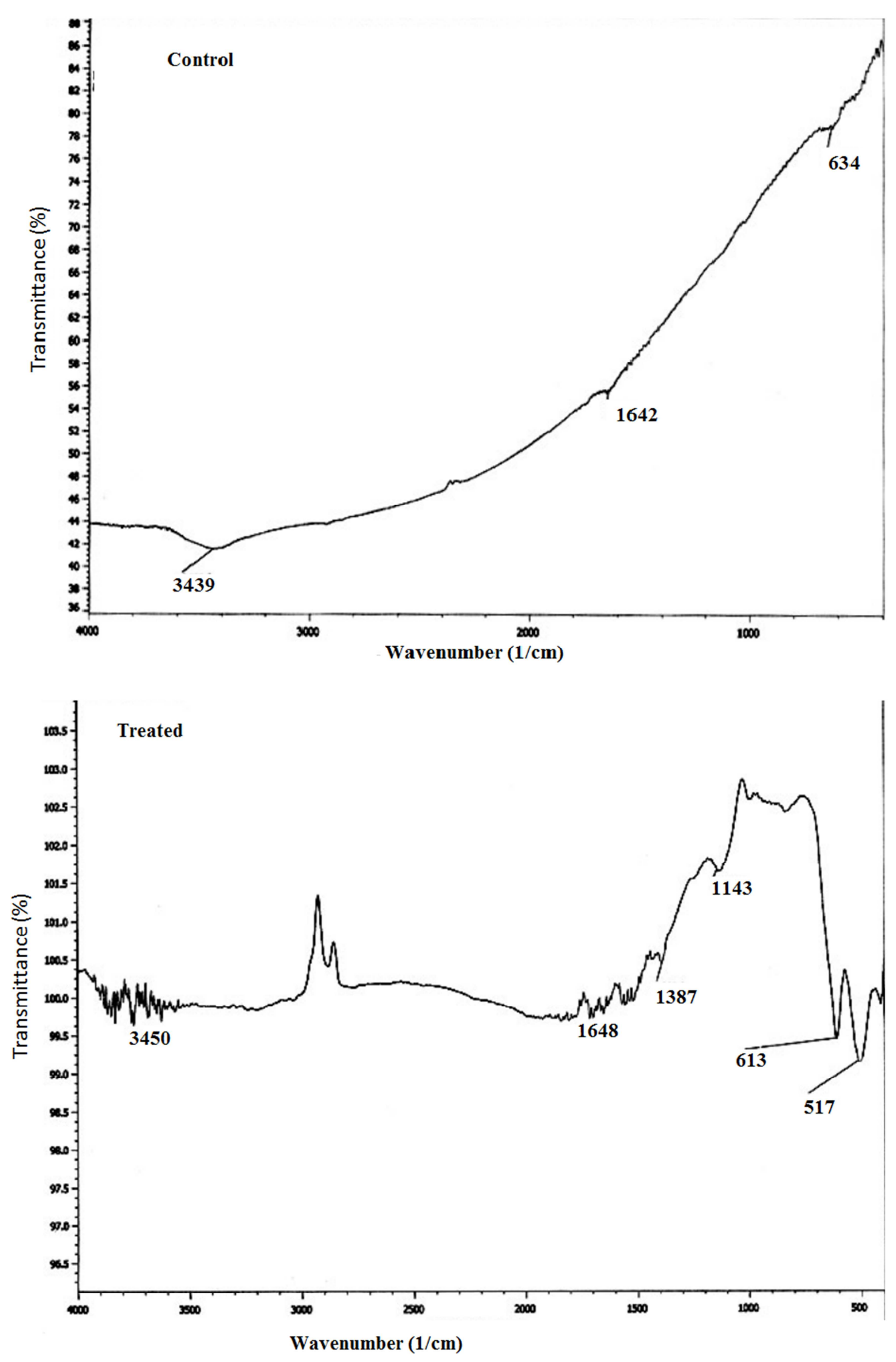

Fig. 3. FT-IR spectra of manganese sulfide nanopowder. 
Here, $\mu$ is the effective mass of atoms, which form the bond and $\mathrm{c}$ is the speed of light $\left(3 \times 10^{8} \mathrm{~m} / \mathrm{s}\right)$. The equation inferred that the reduction of bond force constant can lead to shift the absorption wavenumber toward lower side. Previously, our group reported that biofield energy treatment has altered the bond length of Ti-O bond in barium titanate [30]. Based on this, it is assumed that the bond force constant of Mn-S bond probably increased after biofield energy treatment.

Further, it is possible that the energy transferred through biofield energy treatment probably acted on the atomic bonding level to cause these modifications. Besides, the XRD data showed that the lattice parameter of Mn-S unit cell was increased in treated sample as compared to control. It implied that the distance between two atoms was increased in the treated sample. Due to this, the bond length of the Mn-S bond might be increased in treated sample, as compared to the control. It is well known that the bond length of any bond is inversely proportional to the bond force constant. Thus, the increase in $\mathrm{Mn}-\mathrm{S}$ bond length may lead to reduce the bond force constant.

\subsection{ESR Spectroscopy}

The ESR spectroscopy is widely used to determine the paramagnetic behavior, to detect the presence of unpaired electrons and vacancies in the compounds. The ESR analysis result of control and treated $\mathrm{MnS}$ is illustrated in Table 3. The data showed the g-factor of 2.162 in the control sample due to the presence of unpaired electron present in $\mathrm{Mn}^{+2}$. However, g-factor was reduced to 2.090 in the treated $\mathrm{MnS}$ sample. It indicates that the g-factor was reduced by $3.3 \%$ in the treated sample as compared to the control. The g-factor is related to the angular momentum of the unpaired electrons. Thus it is assumed that the biofield energy treatment probably altered the angular momentum of the electron spin. Further, it was also found that the ESR signal width was reduced by $12.9 \%$ in the treated sample as compared to the control. It indicated that $\mathrm{Mn}$ electrons subjected to the narrow spin-orbit interaction, which might be the responsible for the reduction of ESR signal width [31]. In addition, the signal height was also reduced by $16.7 \%$ in the treated sample as compared to the control. Therefore, ESR results suggested that the energy transferred through biofield treatment probably interact with electron to cause these modification at atomic level.

Table 3. ESR analysis result of manganese sulfide nanopowder.

\begin{tabular}{llll}
\hline Group & g-factor & ESR signal width & ESR signal height \\
\hline Control & 2.162 & 1240 & $1.44 \times 10^{-2}$ \\
Treated & 2.090 & 1080 & $1.20 \times 10^{-2}$ \\
Percent Change & -3.3 & -12.9 & -16.7 \\
\hline
\end{tabular}

\section{Conclusions}

The effect of biofield energy treatment on the atomic and physical properties of MnS was analyzed. The XRD data revealed that the biofield energy treatment has altered the lattice parameter, unit cell volume, density, and molecular weight of the treated $\mathrm{MnS}$ sample as compared to the control. The alteration in molecular weight could be due to the interaction of biofield energy with the neutron and proton of the $\mathrm{MnS}$ nucleus. The crystallite size on crystalline plane (220) was reduced upto $50 \%$ in the treated sample as compared to the control. The change in crystallite size may alter the energy band gap of MnS. Besides, the FT-IR analysis revealed that the absorption band attributed to Mn-S stretching vibration was reduced from $634 \mathrm{~cm}^{-1}$ (control) to $613 \mathrm{~cm}^{-1}$ in the treated $\mathrm{MnS}$ as compared to the control. It may be due to reduction of bond force constant in $\mathrm{MnS}$ through biofield energy treatment. In addition, biofield energy treatment has reduced the g-factor by $3.3 \%$ $(2.162 \rightarrow 2.090)$ in the treated sample as compared to the control. Thus, above data suggested that biofield energy treatment has considerable impact on the atomic and physical properties of MnS. Therefore, the biofield energy treatment could be applied to modify the atomic and physical properties of $\mathrm{MnS}$ for the solar cell and semiconductor industries.

\section{Acknowledgments}

Authors would like to acknowledge Dr. Cheng Dong of NLSC, Institute of Physics, and Chinese academy of sciences for supporting in analyzing the XRD data using Powder-X software. The authors would also like to thank Trivedi Science, Trivedi Master Wellness and Trivedi Testimonials for their support during the work.

\section{References}

[1] Beltran-Huarac J, Resto O, Carpena-Nuñez J, Jadwisienczak WM, Fonseca LF, et al. (2014) Single-Crystal $\gamma$-MnS Nanowires Conformally Coated with Carbon. Appl Mater Interfaces 6: 1180-1186.

[2] Okajima M, Tohda T (1992) Heteroepitaxial growth of MnS on GaAs substrates. J Cryst Growth 117: 810-815.

[3] Goede O, Heimbrodt WH, Weinhold V (1986) Luminescence and excitation spectroscopy of MnS thin films. Phys Status Solidi B 136: K49-K54.

[4] Kennedy SW, Harris K, Summerville E (1980) Mechanisms of thermal transformation of zinc blende to $[\mathrm{NaCl}]$ in $\mathrm{MnS}$ crystals. J Solid State Chem 31: 355-359.

[5] Yang X, Wang Y, Wang K, Sui Y, Zhang M, et al. (2012,) Polymorphism and formation mechanism of nanobipods in manganese sulfide nanocrystals induced by temperature or pressure. J Phys Chem C 116: 3292-3297.

[6] Tian Q, Tang M, Jiang FR, Liu YW, Wu JH (2011) Largescaled star-shaped $\alpha$-MnS nanocrystals with novel magnetic properties. Chem Commun 47: 8100-8102.

[7] Kravtsova KN, Stekhin IE, Soldatov AV, Liu X, Fleet ME (2004) Electronic structure of MS (M=Ca, Mg, Fe, Mn ):Xray absorption analysis. Phys Rev B 69: 134109. 
[8] Zhao P, Zeng Q, He X, Tang H, Huang K (2008) Preparation of $\gamma$-MnS hollow spheres consisting of cones by a hydrothermal method. J Cryst Growth 310: 4268-4272.

[9] Lokhande CD, Ennaoui A, Patil PS, Giersig M, Muller M et al. (1998) Process and characterisation of chemical bath deposited manganese sulphide $(\mathrm{MnS})$ thin films. Thin Solid Films 330: 70-75.

[10] Lu J, Qi P, Peng Y, Meng Z, Yang Z, et al.(2001) Metastable MnS crystallites through solvothermal synthesis. Chem Mater 13: $2169-2172$

[11] Jun Y, Jung Y, Cheon J (2002) Architectural control of magnetic semiconductor nanocrystals. J Am Chem Soc 124: 615-619.

[12] Skromme B, Zhang Y, Smith DJ, Sivananthan S (1995) Growth and characterization of pseudomorphic single crystal zinc blende MnS. Appl Phys Lett 67: 2690-2693.

[13] Veeramanikandasamy T, Rajendran K, Sambath K (2014) Influence of $\mathrm{Mn} / \mathrm{S}$ molar ratio on the microstructure and optical properties of $\mathrm{MnS}$ nanocrystals synthesized by wet chemical technique. J Mater Sci: Mater Electron 25: 33833388 .

[14] Shi Y, Xue F, Li C, Zhao Q, Qua Z (2011) Preparation and hydrothermal annealing of pure metastable b-MnS thin films by chemical bath deposition (CBD). Mater Res Bull 46: 483486.

[15] Trivedi MK, Patil S, Nayak G, Jana S, Latiyal O (2015) Influence of biofield treatment on physical, structural and spectral properties of boron nitride. J Material Sci Eng 4: 181.

[16] Trivedi MK, Patil S, Shettigar H, Bairwa K, Jana S (2015) Phenotypic and biotypic characterization of Klebsiella oxytoca: An impact of biofield treatment. J Microb Biochem Technol 7: 202-205.

[17] Saad M, Medeiros RD (2012) Distant healing by the supposed vital energy- scientific bases. Complementary therapies for the contemporary healthcare. InTech.

[18] Barnes PM, Powell-Griner E, McFann K, Nahin RL (2004) Complementary and alternative medicine use among adults: United States, 2002. Adv Data 343: 1-19.

[19] Trivedi MK, Nayak G, Patil S, Tallapragada RM, Latiyal O (2015) Studies of the atomic and crystalline characteristics of ceramic oxide nano nanopowders after bio field treatment. Ind Eng Manage 4: 161.
[20] Trivedi MK, Nayak G, Patil S, Tallapragada RM, Latiyal O et al.(2015) An evaluation of biofield treatment on thermal, physical and structural properties of cadmium nanopowder. $\mathbf{J}$ Thermodyn Catal 6: 147.

[21] Trivedi MK, Tallapragada RM, Branton A, Trivedi D, Nayak $\mathrm{G}$, et al. (2015) Potential impact of biofield treatment on atomic and physical characteristics of magnesium. Vitam Miner 3: 129.

[22] Trivedi MK, Patil S, Tallapragada RM (2013) Effect of biofield treatment on the physical and thermal characteristics of vanadium pentoxide nanopowder. J Material Sci Eng S11: 001 .

[23] Mi L,Chen Y, Zheng Z, Hou H, Chen W (2014) Beneficial metal ion insertion into dandelion-like $\mathrm{MnS}$ with enhanced catalytic performance and genetic morphology. RSC Adv 4: 19257-19265.

[24] Trivedi MK, Tallapragada RM (2008) A transcendental to changing metal powder characteristics. Met Powder Rep 63: $22-28,31$

[25] Kumar P, Kar M (2014) Effect of structural transition on magnetic and dielectric properties of $\mathrm{La}$ and $\mathrm{Mn}$ cosubstituted $\mathrm{BiFeO}_{3}$ ceramics. Mater Chem Phys 148: 968-977.

[26] Girish M, Dhandayuthapani T, Sivakumar R, Sanjeeviraja C (2014) The effect of TEA on structural and optical properties of nebulized spray deposited MnS thin films. Int J Chem Tech Res 6: 3361-3363.

[27] Wang TX, Chen WW (2008) Low-temperature synthesis of pure rock-salt structure manganese sulfide using a singlesource molecular precursor. Chem Eng J 144: 146-148.

[28] Liu JD, Zheng XS, Shi ZF, Zhang SQ (2014) Sulfur/mesoporous carbon composites combined with $\gamma$-MnS as cathode materials for lithium/sulfur batteries. Ionics 20 : 659-664.

[29] Ghosh M, Dilawar N, Bandyopadhyay AK, Raychaudhuri AK (2009) Phonon dynamics of $\mathrm{Zn}(\mathrm{Mg}$, Cd)O alloy nanostructures and their phase segregation. J Appl Phys 106:1-6.

[30] Trivedi MK, Nayak G, Patil S, Tallapragada RM, Latiyal O, et al. (2015) Impact of biofield treatment on atomic and structural characteristics of barium titanate nanopowder. Ind Eng Manage 4: 166.

[31] Moloto N, Moloto MJ, Kalenga M, Govindraju S, Airo M (2014) Synthesis and characterization of $\mathrm{MnS}$ and $\mathrm{MnSe}$ nanoparticles: Morphology, optical and magnetic properties. Opt Mater 36: 31-35. 